تأثير جنگل كارى با گونه Prosopis juliflora بر خصوصيات فيزيكو شيميايى خاك در تِهاى شنى (بُروهش موردى: منطقه مخران شهرستان شوش)

فاطمه ايمانى، مصطفى مر ادى" و رضا بصيرى'

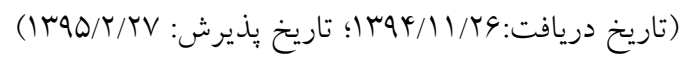

جكيده

با توجه به اهميت حفاظت خاك و جلو خيرى از فرسـايش بادى در اراضى ماسهاى و تأثير جنعل كارى بهاعنوان يكى عامل مؤثر و دائمى در

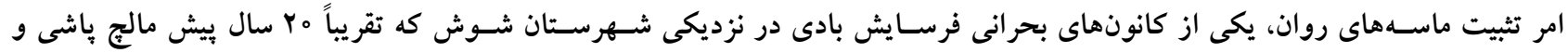

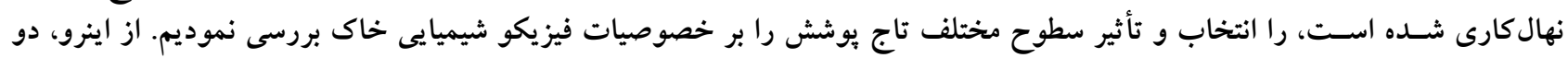

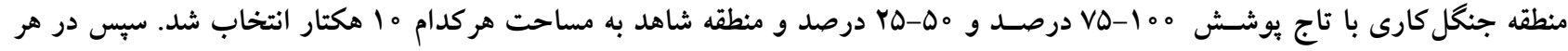

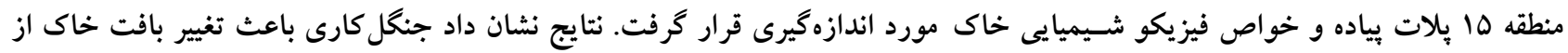

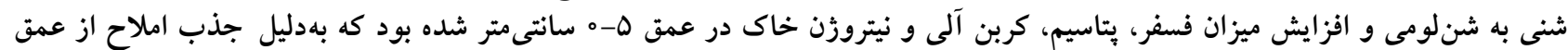

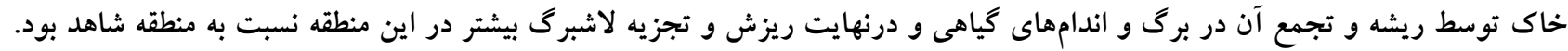

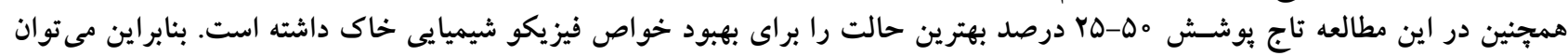

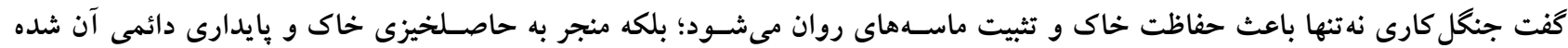

كلمات كليدى: بوشش گياهى، تبههاى ماسهاى، عناصر خاك، تاج يوشش 
ديخرى را نيز بـه جهـت جنبه هاى مديريتى در اختيار تصــميم

كيران قرار دهد (4) (4).

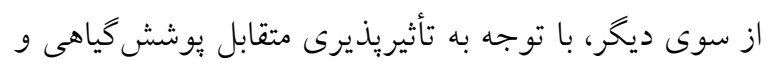

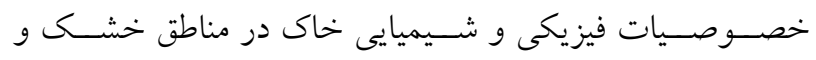

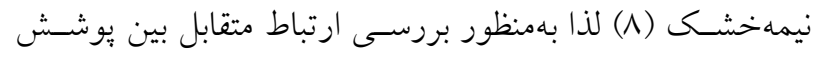

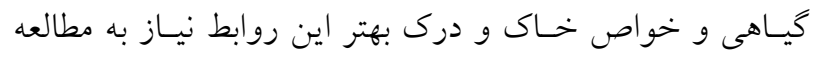
وضسعيت يوشـش كياهى و خاك بعد از اجراى طرحهاى تثبيت

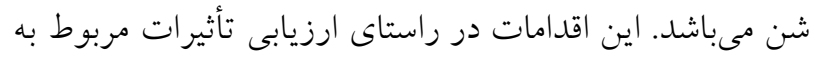
موفقيـت يـا عدم موفقيت طرحهاى اجرايى مىباشـــــــاز اينرو،

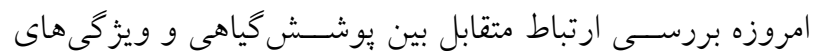

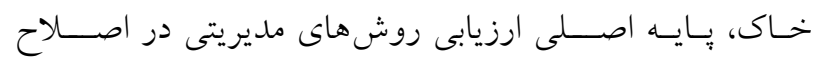

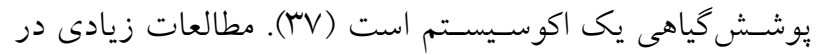

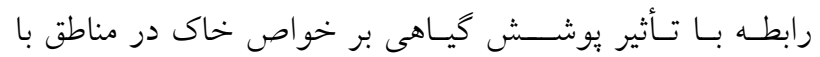

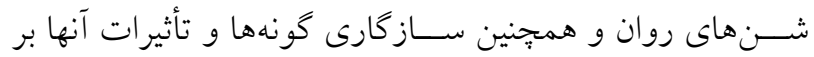
خواص خاك صــورت كرفته اســت كه همخى كوياى اهميت

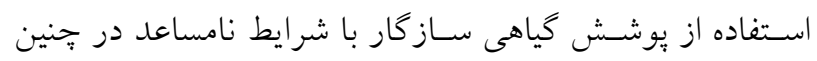

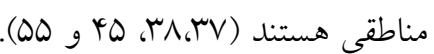

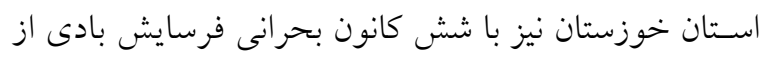

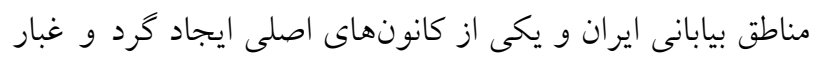

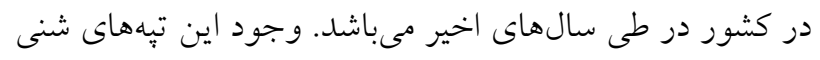

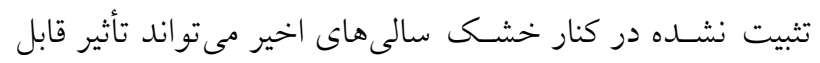

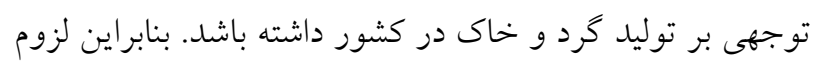

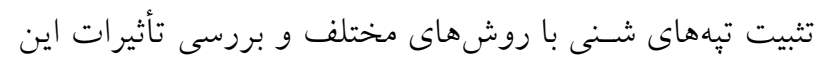

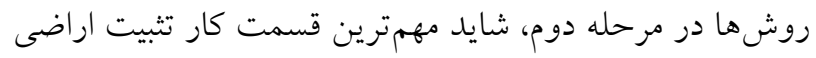

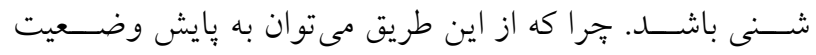
موجود و همجنين تشـخيص بهترين و بايدارترين روش تثبيت

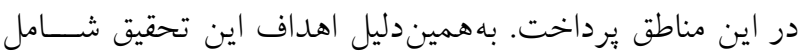
بررسـى 1- ارزيابى بيش از دو دهه فعاليتهاى جنكل كارى بر

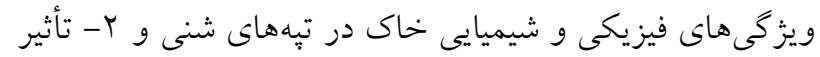

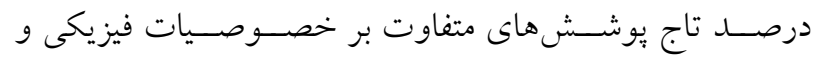
شــيميايى خاك در منطقه جنگكل كارى و مقايســهـ آن با شــاهد

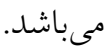

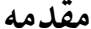
در ايران هم درصد از اراضى، داراى اقليم خشك، نيمهخشك و فراخشى است كه با رشد ساليانه يكدرصدى در حال گسترش مىباشـد ( (1). اين اراضى حدود •م ميليون هكتار هستند كه با

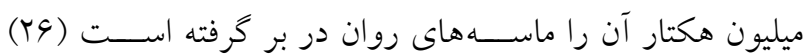
ماسههاى روان اثرات مختلفى ازجمله تهلديد حاصلخيزى خاك،

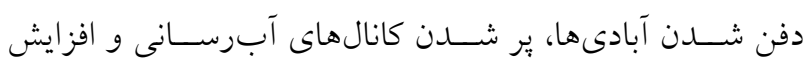

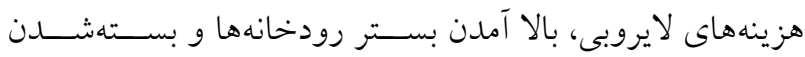

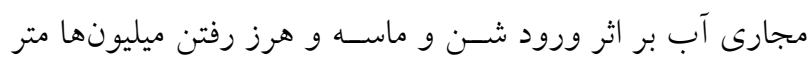
مكعب آب در سـال، افزايش تصــادفات جادهاى بهدليل كاهش ديد، مسدود نمودن جادههاى ارتباطى، آلوده شدن محيط زيست و در خطر افتادن سلامتى ساكنين منطقه را در يى دارد (V). از اولين اقـدامـات براى تثبيـت مـاســـهـهاى روان و كنترل فرسايش بادى، مىتوان به استفاده از مالجهاى حفاظتى در سطح خاك اشـاره كرد. ولى امروزه اسـتفاده از مالجهاى نفتى بهعلت مشـكاتلات و محدوديتهايى كه به همراه دارد، كمتر مورد توجه مىباشــــ (19 و 11). از ســوى ديخر، مالجهاى غيرنفتى نيز از قبيل مواد آلى و كود حيو انى بهدليل گران بودن استفاده نمىشوند

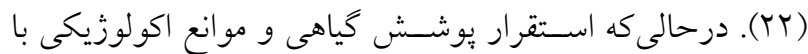
كمترين آسـيب، مىتواند بيشـترين تأثير را در كاهش فرسـايش بادى و بهبود وضــعيت اكولوزيكى منطقه داشـــه باشـــــ (10). اسـتقرار يوشـش گياهى به طور مؤثرى كاهش حركت ماسههاى

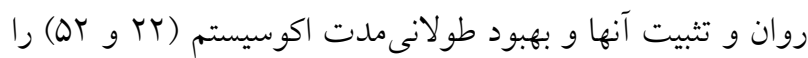

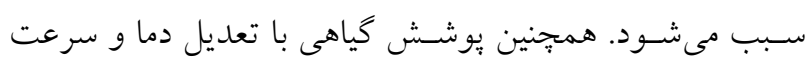
بـاد (11) و افزايش نفوذيذيرى آب و ظرفيت نخهدارى رطوبت

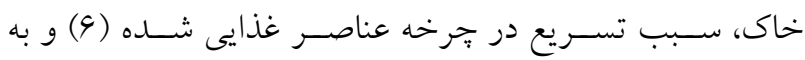
استقرار كونهاى ديخر و تحول خاك منطقه (YYY) كمك كرده و درنتيجه اثرات منفى ناشسى از شنهاى روان را در منطقه كاهش

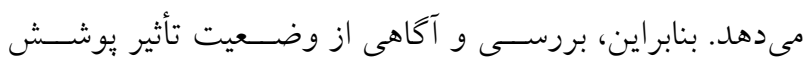
كيـاهى بر اين اراضـىى، مىتواند علاوه بر ايجاد اطلاعات لازم بـهنمنظور يـايش وضـــيت خاك و گياه در هر منطقه، اطلاعات 


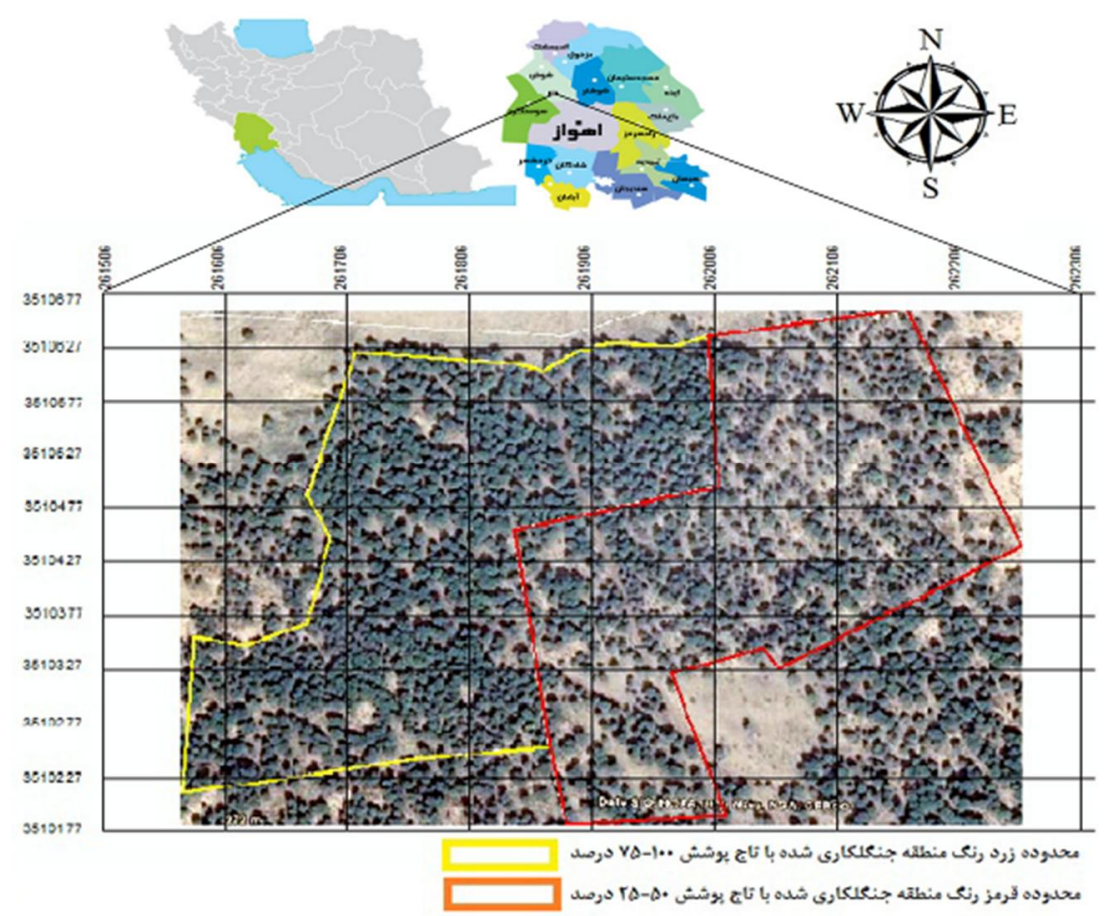

شكل ا. موقعيت منطقه مورد مطالعه

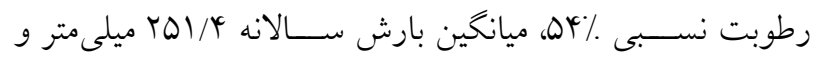

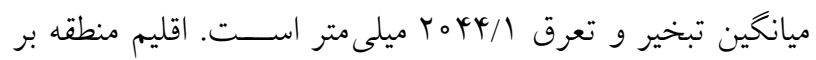

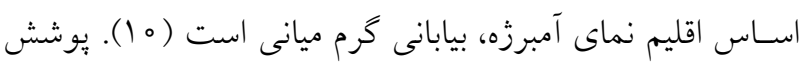

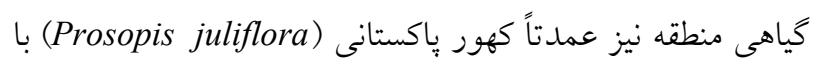
زيراشـكوب ينىزيتوم (Pennisetum orientallis) و اسـكنبيل مىباشـــد كه از بوشــش درختى و (Calligonum comosum) مرتعى تشكيل شده، يوشش درختى آن داراى دو تيٍِ انبوه كهور پاكستانى و تيب تنى كهور- اسكنبيل است (10). با توجه به وســعت زياد منطقه جنخل كارى شــده (حدود V900 هكتار) و وجود تودههايى با تاج :يوشش متفاوت، دو توده •ا هكتارى به دور از اثر حاشيهاى (مانند رودخانه كرخه، جراى دام ساكنين منطقه، اراضى نسق مجاور طرح) كه براى رسيدن به اهداف يروزه مناسب باشد، مشخص شد. دو توده با تاج بوشش

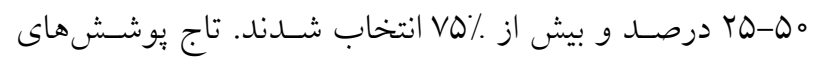
مورد نظر بــا اســفاده از شــبكه نقطه تجين برروى تصـــاوير ماهوارهاى مشـخص شد (I I). لازم به ذكر است كه منطقهاى به مساحت ه ا هكتار نيز بهعنوان منطقه شاهد در

\section{مواد و روشها}

منطقه مورد مطالعه

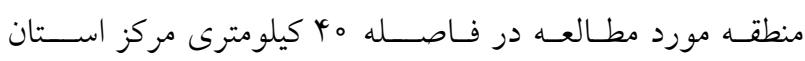
خوزستان در شمال شهر اهواز و جنوب شهر شوش و در ضلع غربى رودخانه كرخه به مختصسـات جغرافيايى "Y "r به جنوبى و روى يهنههاى ماسـهاى قرار دارد (شكل (1). بهدليل عدم يايدارى و دوام خاك، جهش مداوم ذرات ماســه و حركت تودهاى عظيم ماسـهاى اسـتقرار طبيعى گياهان در اين منطقه با مشـكل مواجه بوده اسـت. اين منطقه بعد از مالج پِاشى در سال

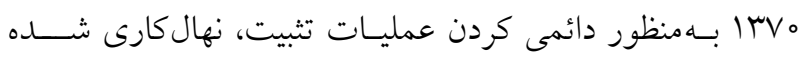

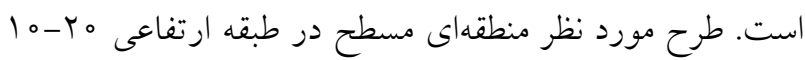
متر و با شــيب بســيار كم r-ه درصسـد و داراى حداقل نقطه ارتفاعى ها متر و حداكثر qو متر از ســطح دريا اســت. جهت عمومى شـيب، شـمال غربى به جنوب شـرقى اسـت. خاك اين منطقه سـبك و فاقد لايه غيرقابل نفوذ و از رده انتى سـول است

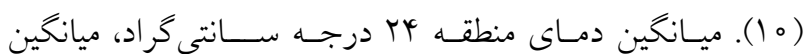




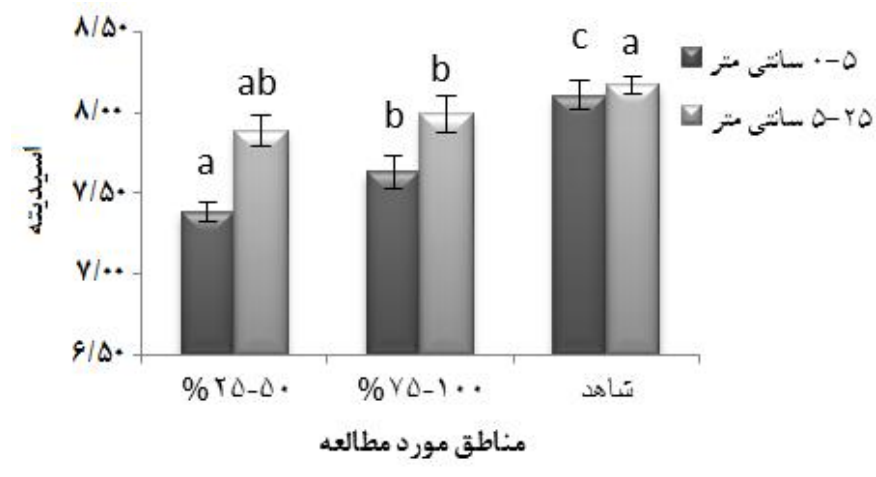

شكل r. مقايسه ميانگين و نتايج دانكن در مقدار pH خاك در سه منطقه مورد نظر

تيمار شــاهد و همدجنين ها تكرار در هر منطقه و براى هر افق

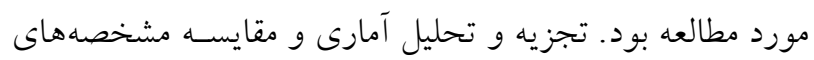

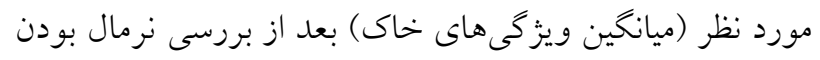

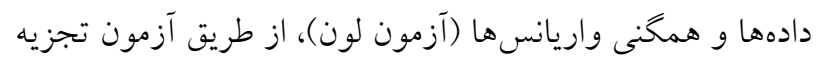

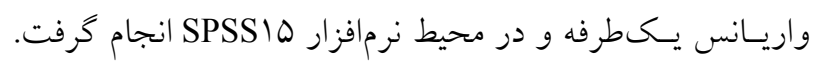

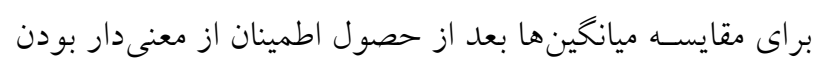

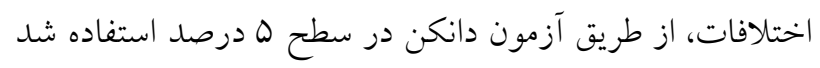

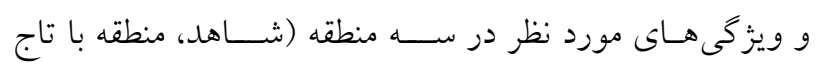

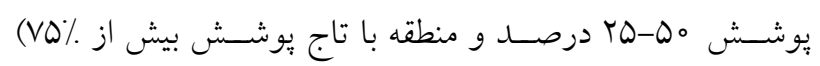

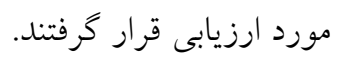

\section{نتايج}

تأثير جنغل كارى بر خواص فيزيكى و شيميايى خاى

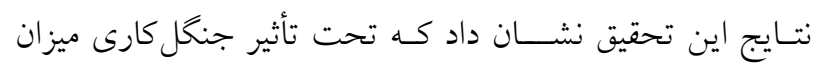

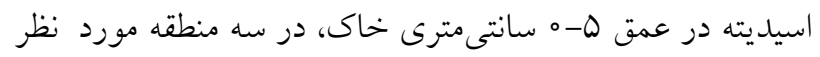

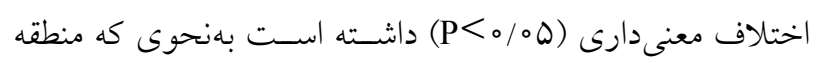

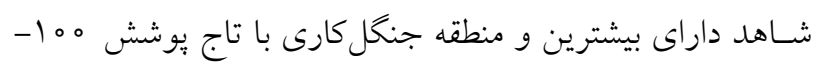

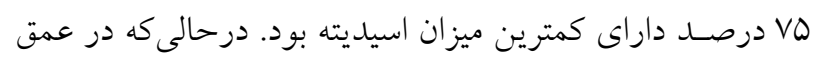

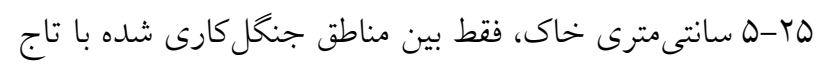

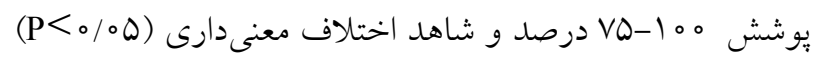

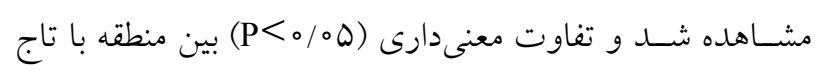

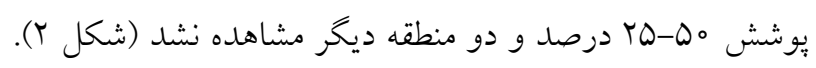

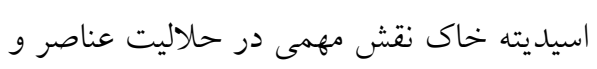

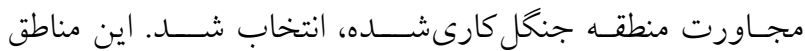

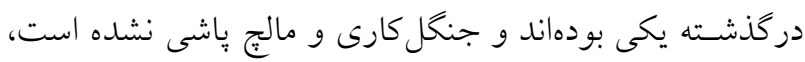

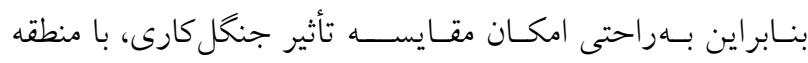
شنهاى روان مجاور آن وجود دارد.

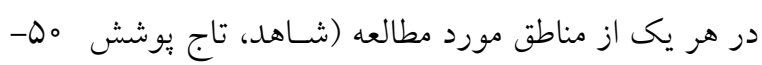

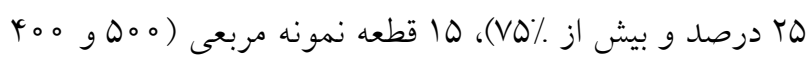

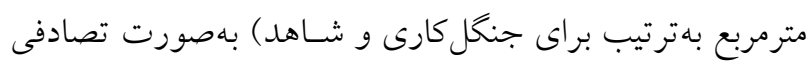

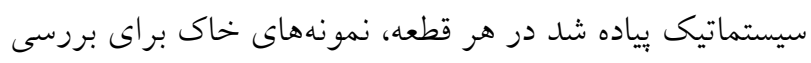

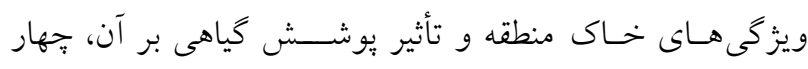

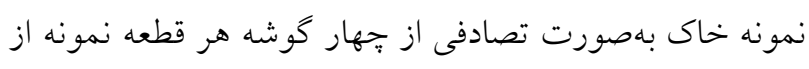

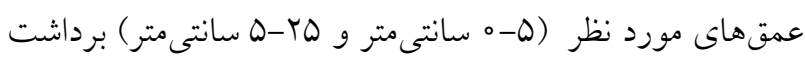
و بعد از تركيب كردن نمونههاى مربوط به هر عمق و و تهيه نمونه

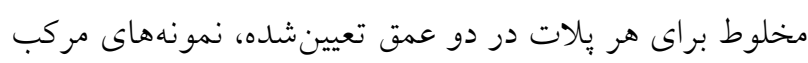

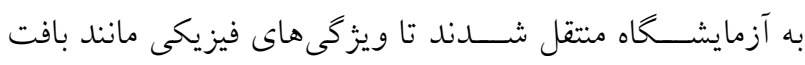
خاى به روش هيدرومترى (rr)، رطوبت به طريق وزنى (Y) (Y) و

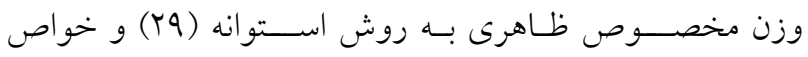

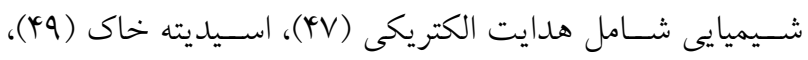

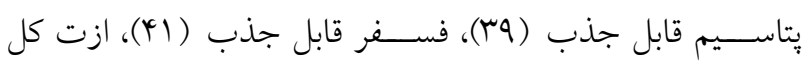

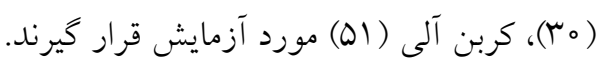

\section{تجزيه و تحليل آمارى}

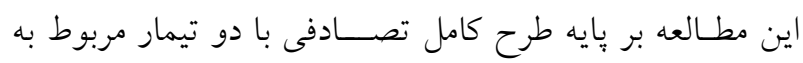

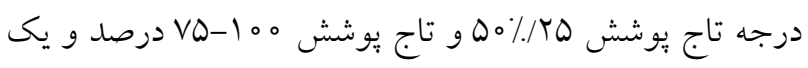




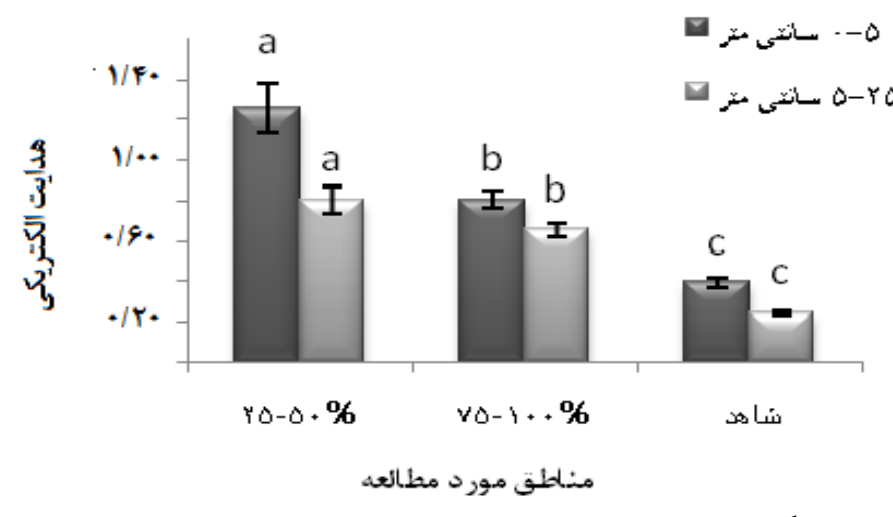

شكل r. مقايسه ميانكين و نتايج دانكن در مقدار هدايت الكتريكى خاك در سه منطقه مورد نظر

تـأثير كـذار و كـاهش تـاج يوشــش منجر بـهـ افزايش هــايت

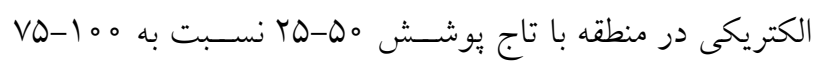

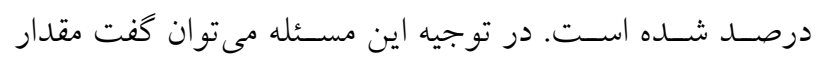

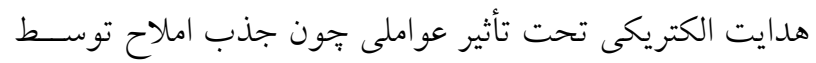

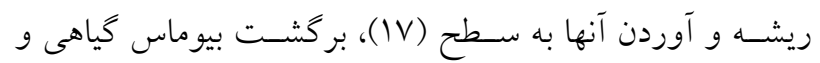

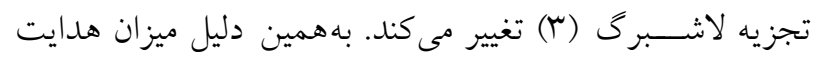

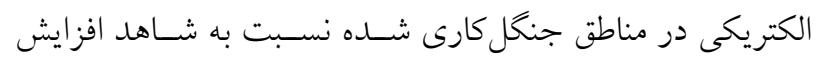

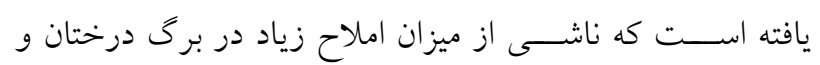

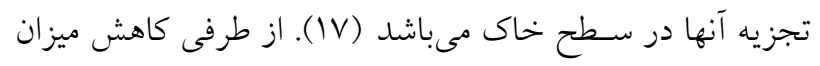

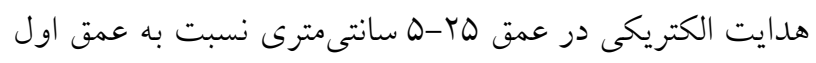

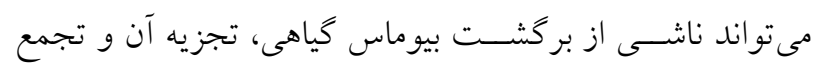

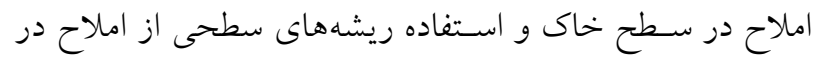

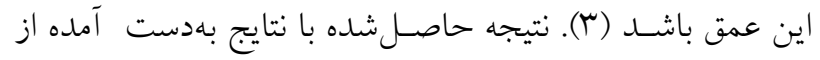
مطالعه نجفى تيره شبانكاره و جليلى (YY) همخروانى دارد.

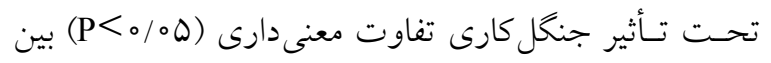

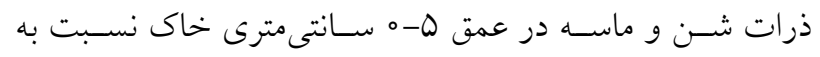

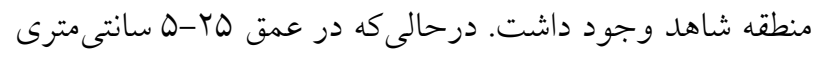

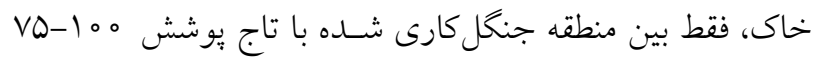

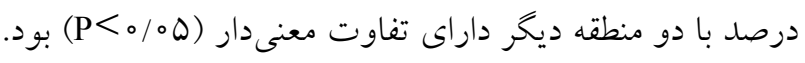

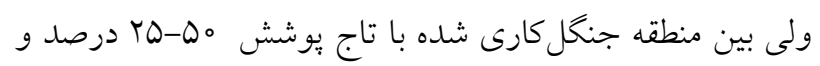

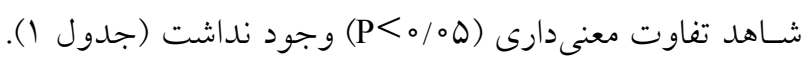

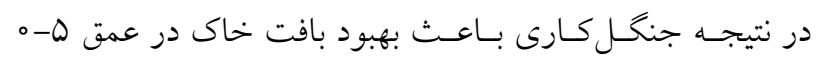
سانتى مترى شده بود. در واقع بعد از تئه
جذب عناصـر غذايى دارد. بنابر اين اطلاع از وضسعيت اسـيديته

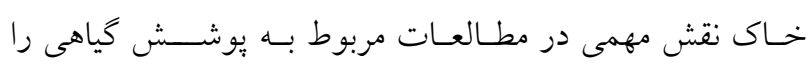
داراست. در اين مطالعه نيز مشخص شد كه ده جنشل كارى با كونه

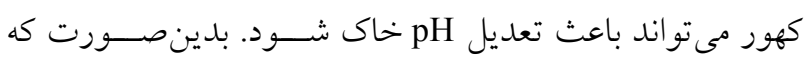

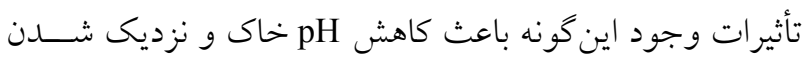

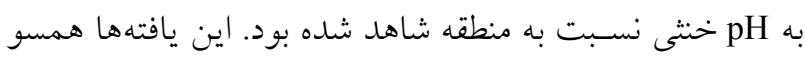

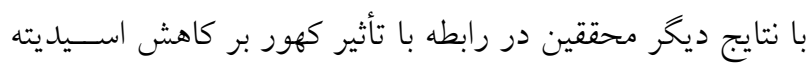

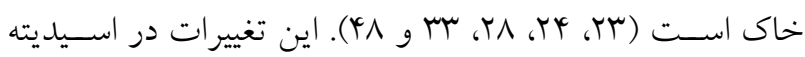
خاك مىتواند ناشى از اسيدهاى آلى ترشحشده از ريشه كياهان

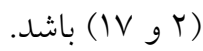
هدايت الكتريكى ويزّكى ديخرى بود كه در اين مطالعه مورد

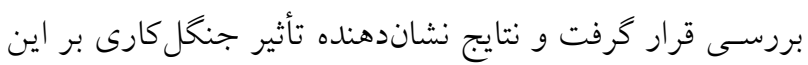

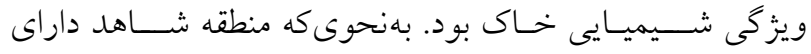

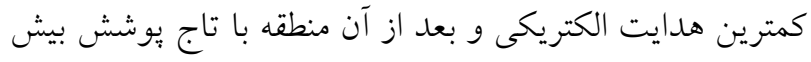

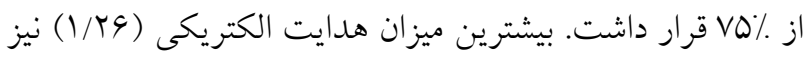

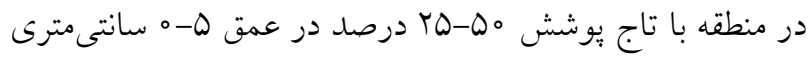

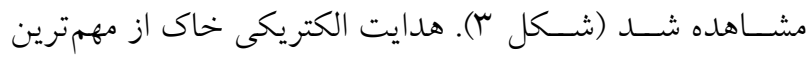

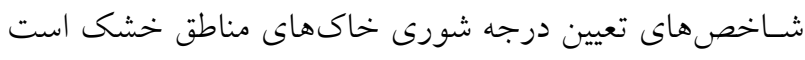

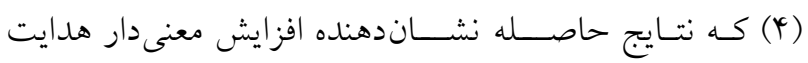

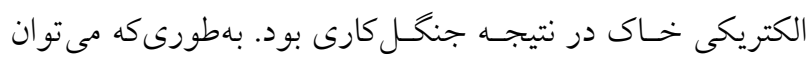

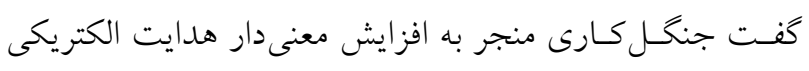

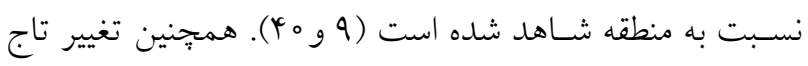

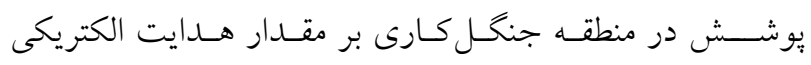


جدول 1. مقايسه ميانكين و نتايج دانكن از خواص فيزيكى خاك در بين سه منطقه مورد نظر

\begin{tabular}{|c|c|c|c|c|c|c|c|}
\hline بافت & درص & ماسه (درصد) & سيلت (درصد) & رطوبت & وزن مخصوص & عمق مورد & منطقه \\
\hline شنلومى & $\circ$ & $r \pm 9 \circ / 0 r^{\mathrm{bb}}$ & $r \pm 1 \circ / 0 r^{a}$ & $r \pm 19 / 0 q^{a b}$ & $1 / \circ \pm r q / \circ \circ r^{b}$ & $\circ-\phi$ & تاج يوشش \\
\hline 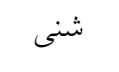 & 。 & $1 \pm 94 / r_{\circ} a$ & $1 \pm 9 / Y_{\circ} a$ & $r \circ / 0 \pm 9 V / \Lambda r^{a}$ & $1 / \circ \pm Q 1 / \circ \circ Y^{b}$ & $\Delta-r \omega$ & $\%$ \%Q-Q。 \\
\hline شنلومى & $\circ$ & $\wedge q / r_{ \pm} \wedge \vee / \Delta q^{b}$ & $1 \circ / r \pm 1 r / \Delta \varphi^{a}$ & $r_{0} / 0 \pm r_{0} / 9 \Lambda^{\mathrm{a}}$ & $1 / \circ \pm \varphi q / \circ \circ r^{b}$ & $\circ-\phi$ & تاج يوشش \\
\hline شنلومى & 。 & $q r / \circ \pm q r / \Lambda^{b}$ & $\mathrm{Q} / \circ \pm \mathrm{V} / \wedge^{\mathrm{b}}$ & $r_{0} / \circ \pm 9 r^{\prime} / M^{a}$ & $1 / \circ \pm Q 1 / \circ \circ Y^{b}$ & $\Delta-r \Delta$ & $\% V \Delta-100$ \\
\hline شنى & $\circ$ & $q r / I \pm Y^{q} V / / r^{a}$ & $q / 1 \pm \Delta r_{/} / r^{\mathrm{b}}$ & $\mid N / 1 \pm 9 \circ / 0 \circ b$ & $1 / \circ \pm 01 / \circ \circ r^{a}$ & $\circ-\phi$ & \multirow[t]{2}{*}{ شاهد } \\
\hline شنى & $\circ$ & $q r / \circ \pm r V / 4 q^{a}$ & $\Delta / \circ \pm V{ }^{\mu} / 4 \varphi^{a}$ & $r \circ / 0 \pm 9 V / V T^{a}$ & $1 / \circ \pm \Delta r / \circ \circ \mu^{a}$ & $\Delta-r \Delta$ & \\
\hline
\end{tabular}

حروف يكسان دهنده عدم تفاوت معنى دار در هر عمق مى باشد

اين تحقيق نشــان داد كـهـ جنخــل كـارى بــاعـث كـاهش وزن

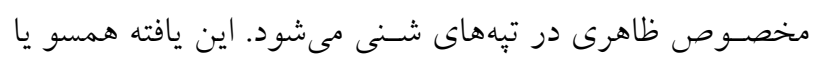

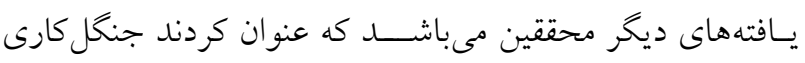

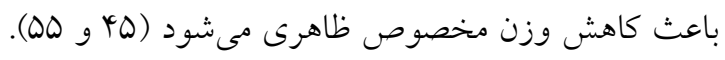

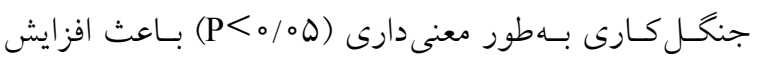

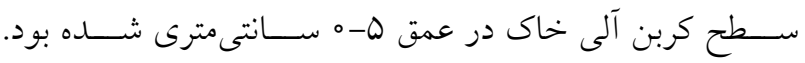

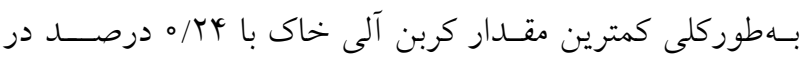

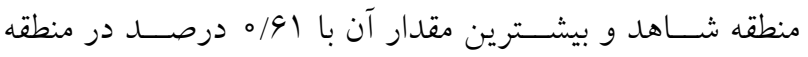

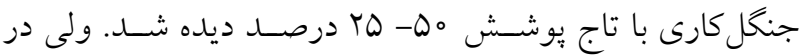

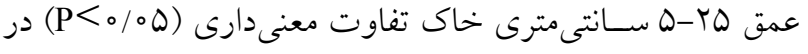

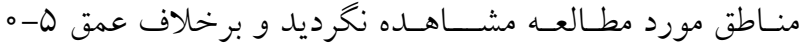
سـانتىمتر بيشـترين ميزان كربن آلى در منطقه شـاهد مشـاهده

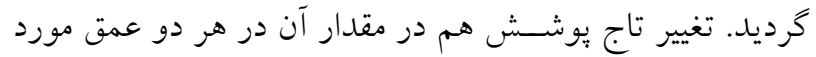

نظر، تفاوت قابل ملاحظهاى را سبب نشده است (شكل ث). افزايش كربن آلى خاك را مى توان ناشـى از افزايش مقدار

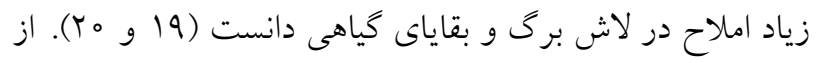

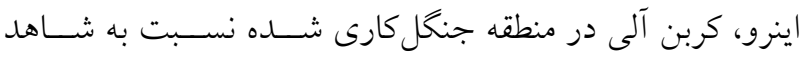
بيشـتر بوده كه همسو با افتهاى ديكر محققين در رابطه با تأثير

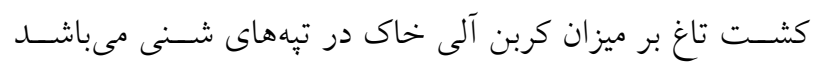

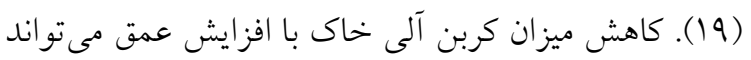

بيش از دو دهه شـاهد يكى روند كاهشسى در مقدار ماسـه و يكى

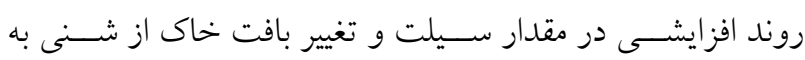

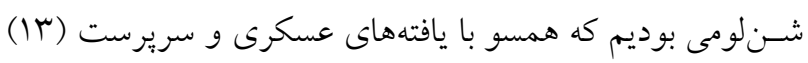

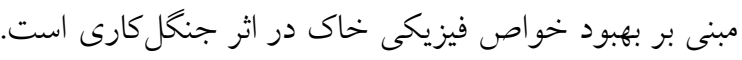

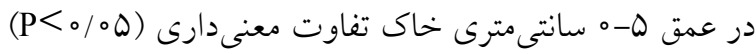

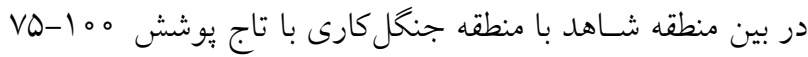

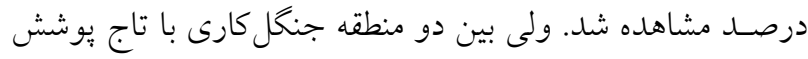

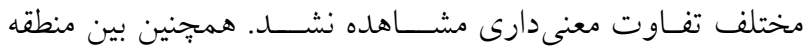

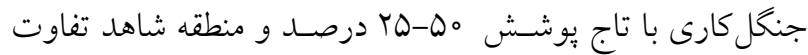

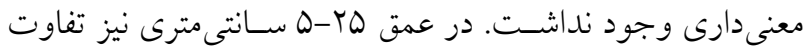
معنى دارى در بين سـه منطقه مورد مطالعه مشـاهده نشـــ (جدول

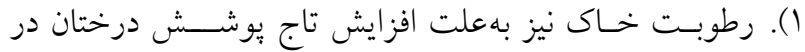

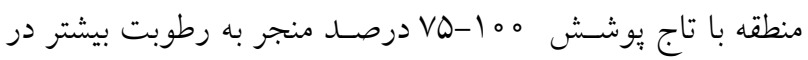

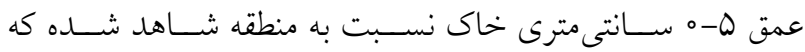

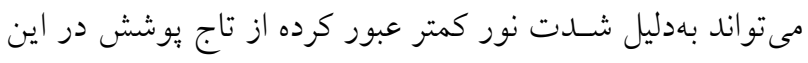
منطقه نسبت به منطقه شاهد به سطح خاك باشد.

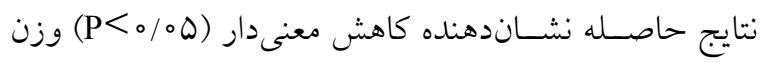

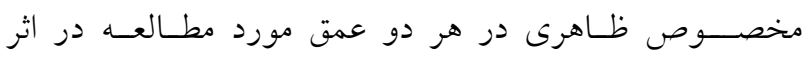

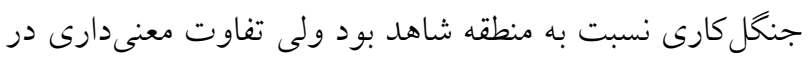

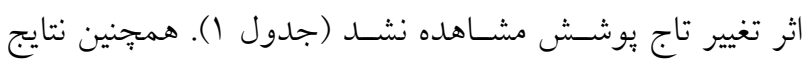




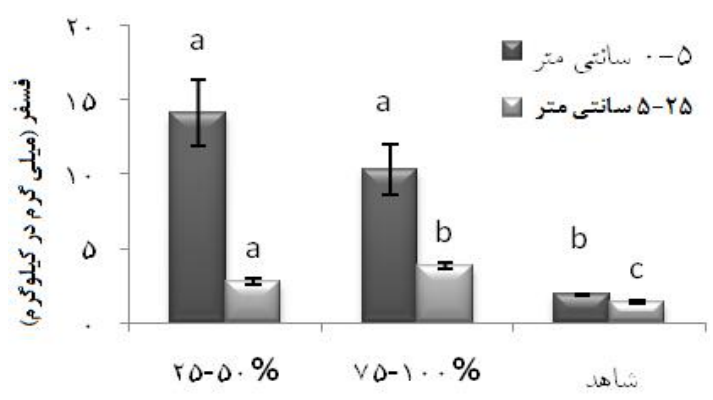

مناطق مورد مطالعه

شكل ه. مقايسه ميانگين و نتايج دانكن در مقدار فسفر مونه (P) خاك در سه منطقه مورد نظر

جنخا كارى شـده مقدار فسـفر همواره بيشتر از شاهد و در افق اول نيز همواره بيشـتر از افق دوم است (V و وهم) كه اين نتيجه

با ساير مطالعات همخوانى دارد (Y أو (r). ميزان يتاسيم در عمق ه-ه سانتى مترى خاك در مناطق مورد

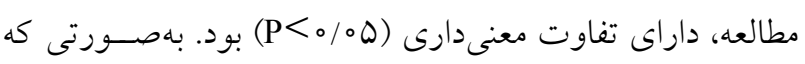

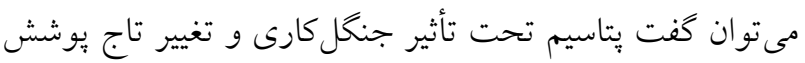
بهطور قابل محسـوسى تغيير كرده است. ولى نتايج بهدست آمده از عمق هץ-ه ســانتىمترى خاك نشــان دهنده تفاوت معنى دار

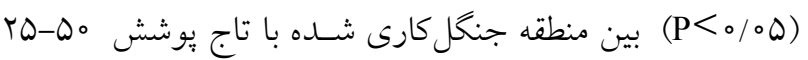
درصد و دو منطقه ديخر بود. ولى بين منطقه شاهد و جنگل كارى

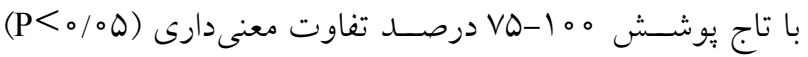
مشاهله نشد. در هر دو عمق مورد مطالعه بيشترين مقدار يتاسيم

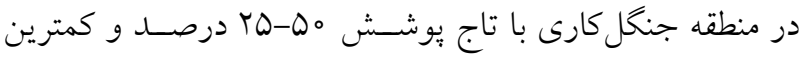
مقدار آن در منطقه شاهد مشاهده كرديد (شكل 9). جنگل كارى تأثير معنى دارى در يتاسيم خاى داشته است. در اين خصـوص مىتوان افزايش يتاسـيم را ناشى از جذب پِّاسيم از اعماق خاى توسط گياه، تجمع آن در برگ و درنهايت تجزيه لاشـبرگ (r و TO) دانست. از ديخر عوامل مؤثر در تغيير يتاسيم

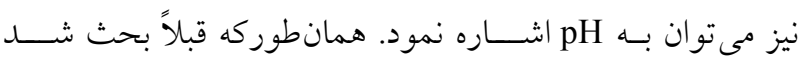
جنخل كارى باعث كاهش pH خاى شده بود كه همين عامل نيز مى توانــد دليلى ديخر بر افزايش يتــاسـيم خـاك در نتيجـهـ

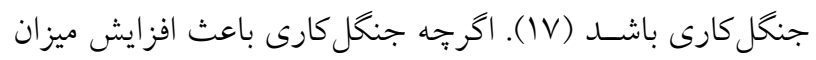
بتاسيم خاك شده است اما در جنگل كارىها با افزايش عمق

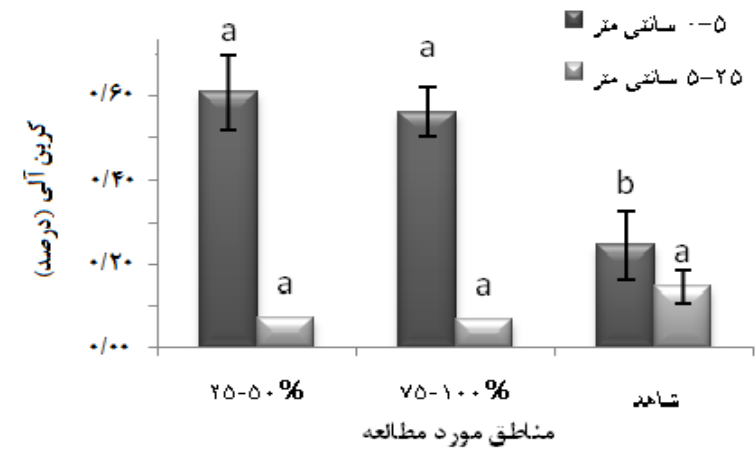

شكل F. مقايسه ميانگين و نتايج دانكن در مقدار كربن آلى (OC) خاى در سه منطقه مورد نظر

بهعلت تفاوت در تجزيه لاشبرى در سطح خاى نسبت به عمق

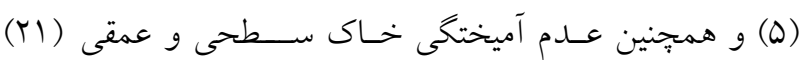
كـاهش بيدا مى كند. افزايش درصــــ تاج بوشــش نيز منجر به

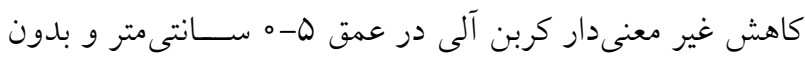
تأثير در عمق QY-ه سانتىمتر بود. در عمق ه-ه سـانتى مترى خاك، بيشـترين ميزان فسـفر در

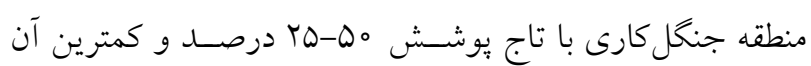
در منطقــه شــاهـــ و تفـاوت معنى دارى (P</D) بين منـاطق جنخل كارى شــده و شـاهد وجود داشـتـ. ولى در اين عمق، با تغيير تاج يوشـش تفاوت معنىدارى (P< > P در مقدار فسـفر خاك سـبب نشـده بود. درصورتى كه در عمق ه广 ه-ه سانتىمترى خاك، نه تنها جنگل كارى نسبت به منطقه شاهد منجر به تغييرات محسـوس در فسـفر خاك شده بلكه تغيير تاج بوشش نيز عامل مؤثر بر مقــدار فســفر خـاك بوده كـهـ بــاعـث تفاوت معنى دار (P<०/D) سـانتى متر بيشـترين مقدار در منطقه جنغل كارى با تاج بوشـش ه DQ-10 درصد و كمترين مقدار در منطقه شاهد بود (شكل ه).

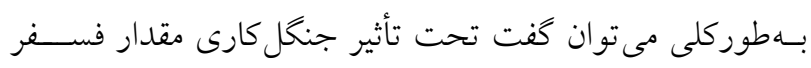
خاك نيز در هر دو عمق مورد نظر نسبت به منطقه شاهد افزايش بيدا كرده بود كه تهويه مناسـب خاك، افزايش لاشبرى و تجزيه آن بهوســــله ميكرو اركانيســـمها منجر به افزايش كربن آلى و كاهش pH خاك شــده كه از عوامل مؤثر بر افزايش فسـفر قابل

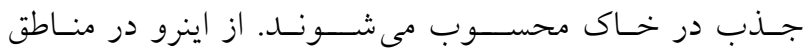




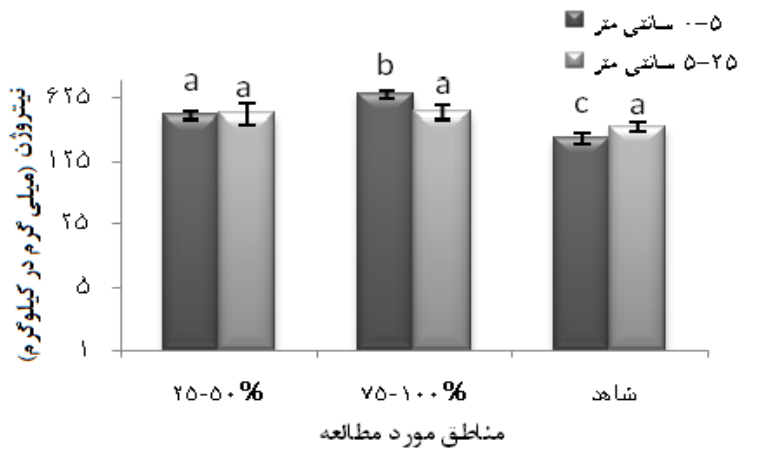

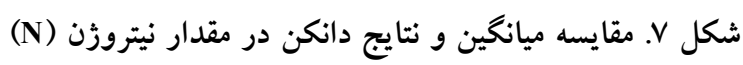
خاك در سه منطقه مورد نظر

معنى دارى كمتر از جنشـل كـارى اسـت ) بـهدليل فرآيند تجزيه

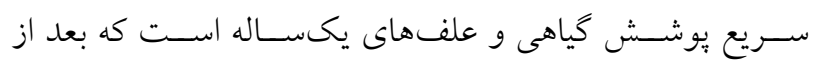

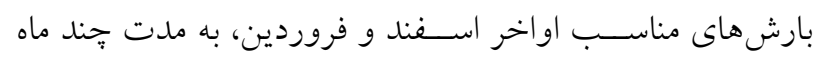
ســبز شـــه و بعد از دوره رويش كوتاهمدت بهســرعت از بين

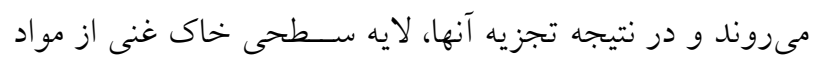
غذايى مى شودد.

\section{نتيجه گيرى}

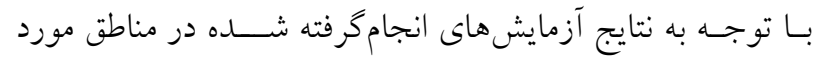
مطالعه مشـخص شـــ كه درصد تاج بوششهاى مختلف مى تو تواند اثرات معنى دارى بر خصــوصـيات فيزيكى و شــيميايى خاك در

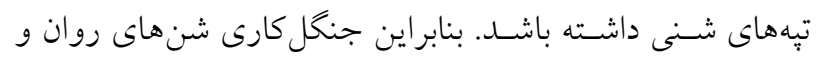

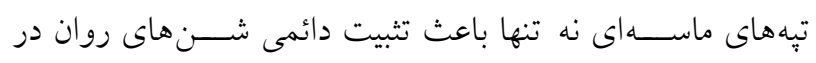

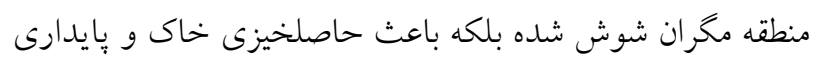

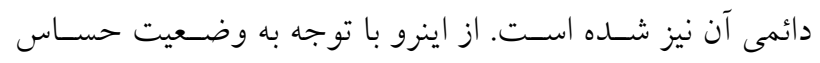

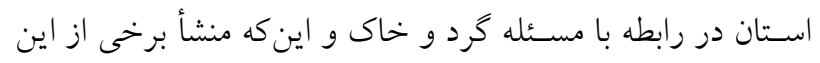

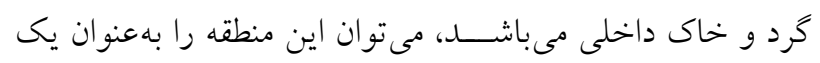

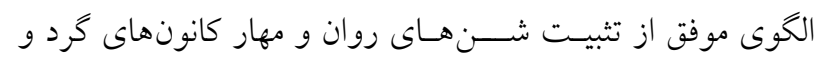

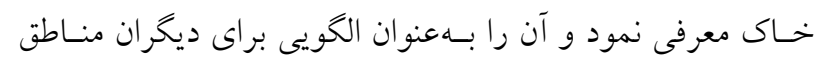

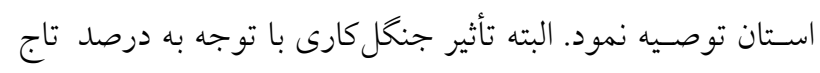

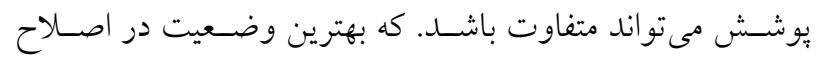

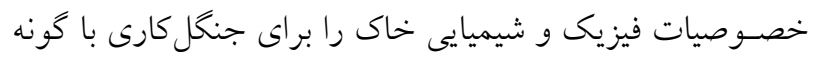

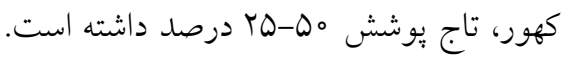

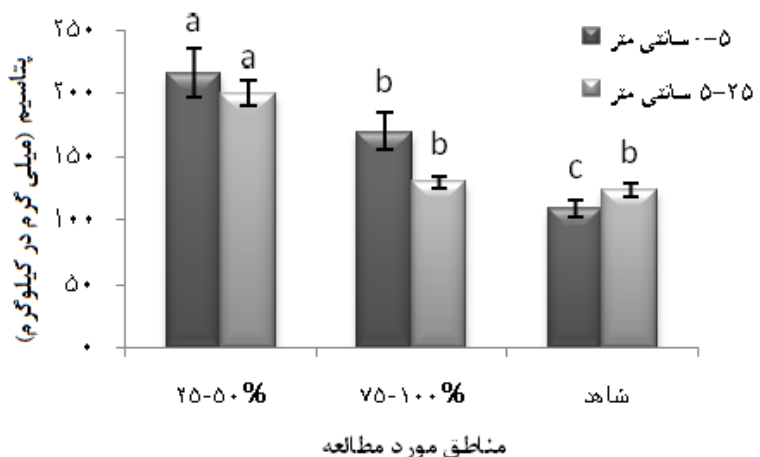

شكل 9 مقايسه ميانگين و نتايج دانكن در مقدار بتاسيم (K) خاك در سه منطقه مورد نظر

خاك يكروند كاهشى در عمق ه-ه سانتىمترى نسبت به عمق

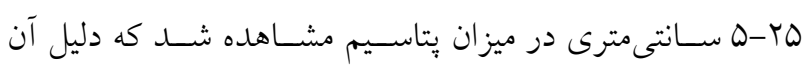

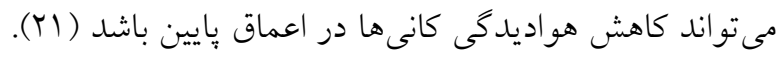

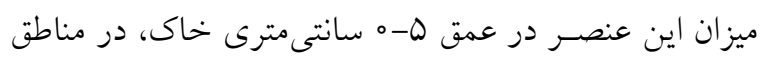

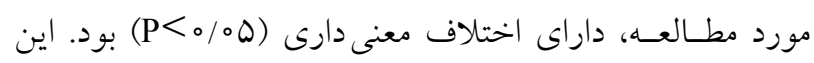

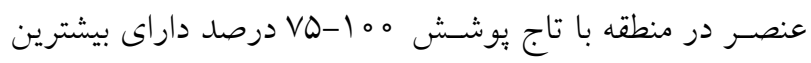

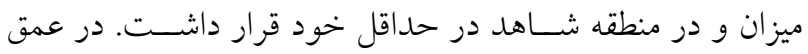

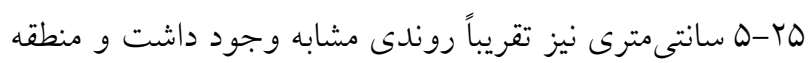

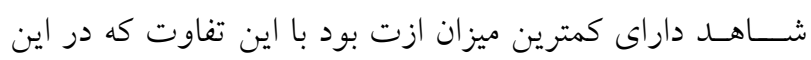

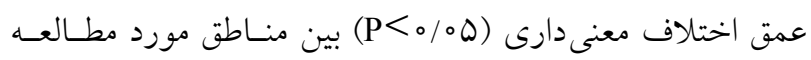

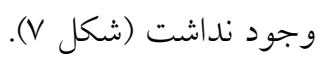

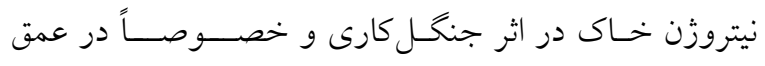
سـطحى خاك افزايش بيدا كرده بود. علت اين مسئله را مى توان

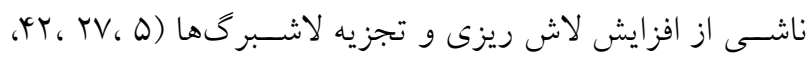

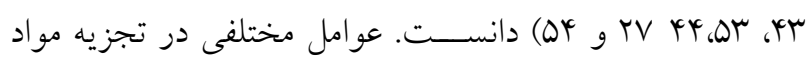

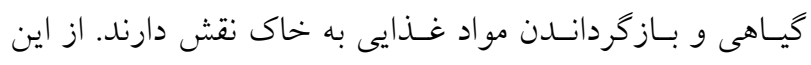

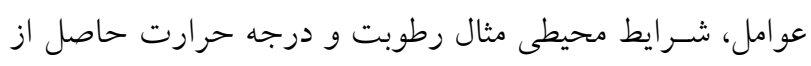

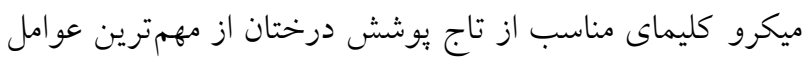

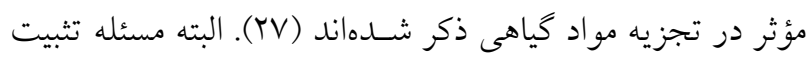

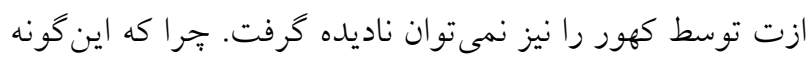

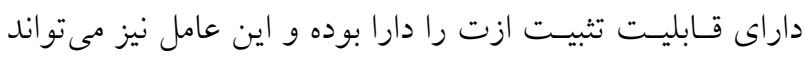

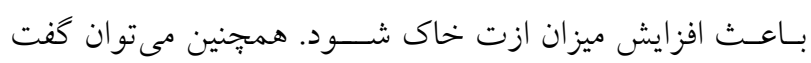

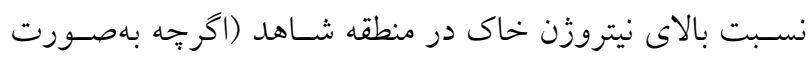


فراهم آوردن امكانات اوليه براى اين تحقيق.

سباسكزارى

با ســاس از دانشـاه صـنعتى خاتم الانبياء (ص) بهـهان بهسبب

\section{منابع مورد استفاده}

ا. بخشنده مهر، ل.، س. سلطانى و ع. سبهر. rوץrا. ارزيابى وضعيت فعلى بيابانزايى و اصلاح مدل مدالوس در دشت سگزى اصفهان.

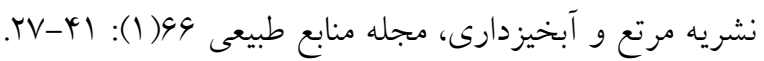

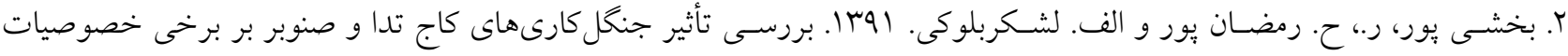

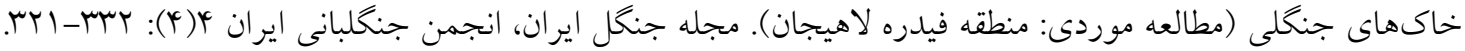

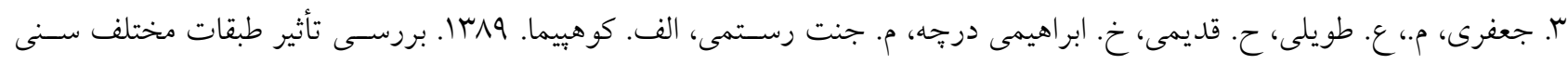

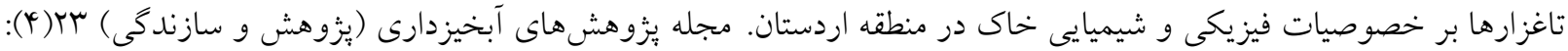

rV-ry

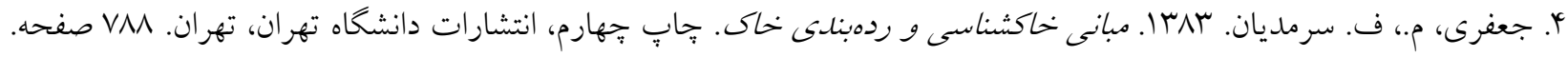

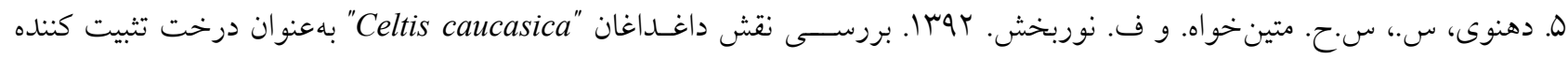

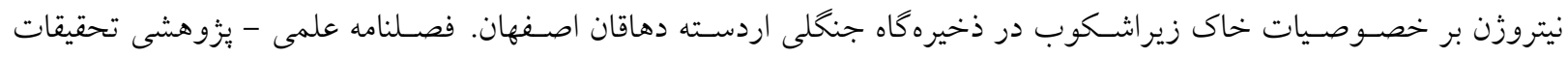

$$
\text { جنگل و صنوبر ايران آY(Y): }
$$

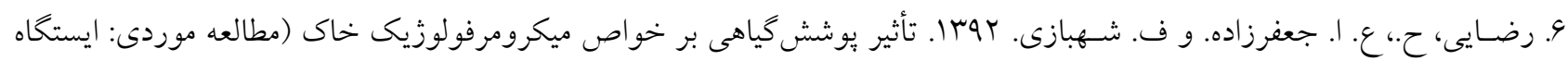

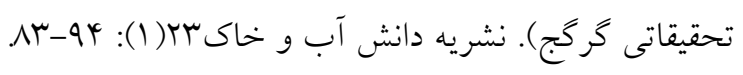

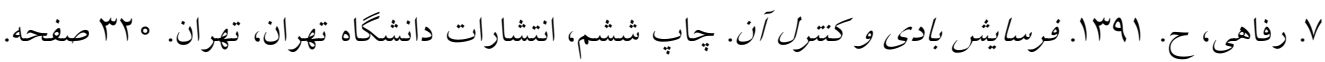

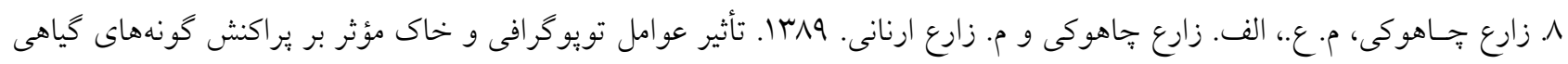

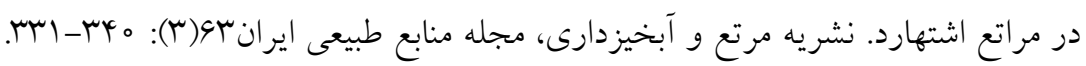

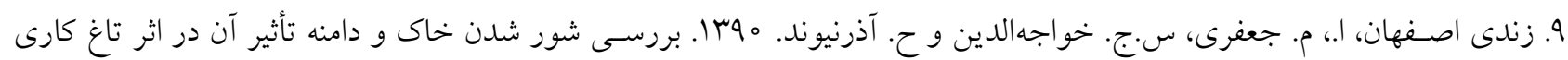

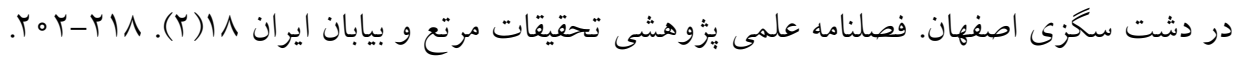

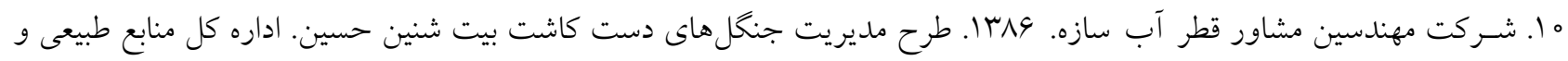
آبخيزدارى خوزستان، اهواز.

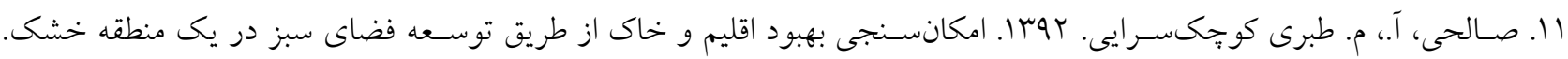

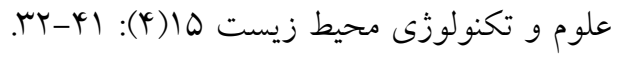

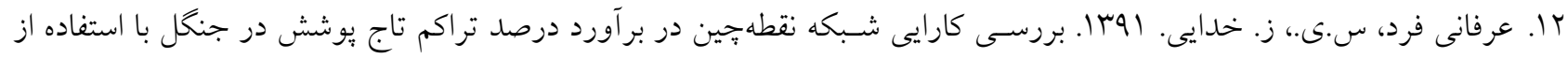

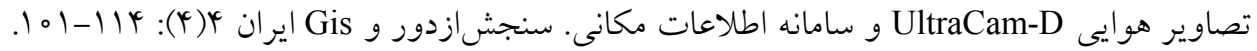
rا. عسكرى، ح.ر.، م. سـريرست. rar|. تأثير تاغ كارى برروى شاخص هاى فرسايشيذيرى خاك در اراضى ماسهاى تايباد. فصلنامه

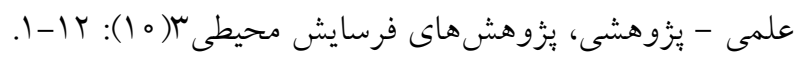

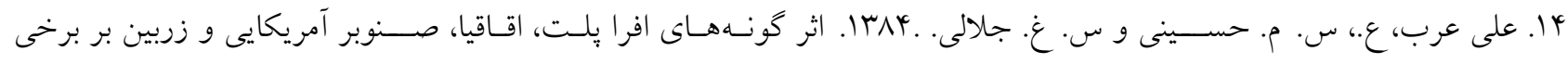

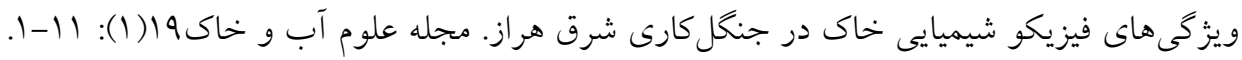




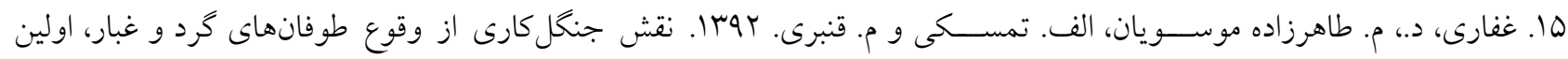

$$
\begin{aligned}
& \text { همايش سراسرى كثاورزى و منابع طبيعى بايدار. 9-1. }
\end{aligned}
$$

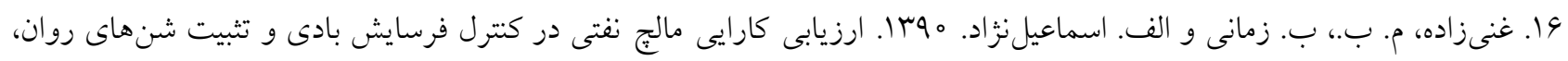

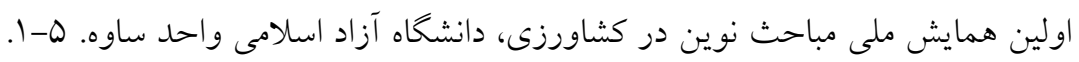

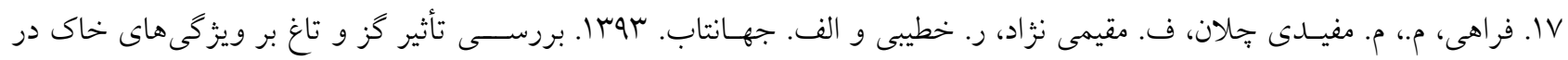

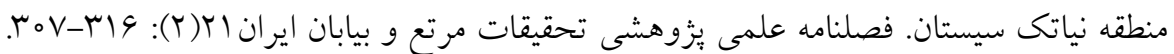

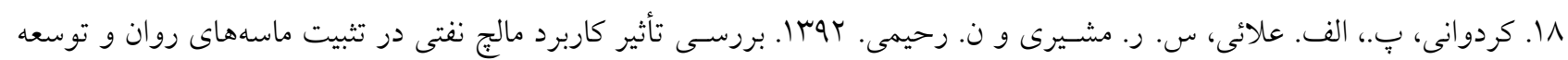

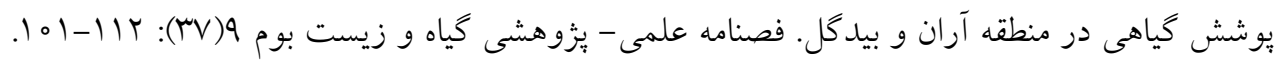

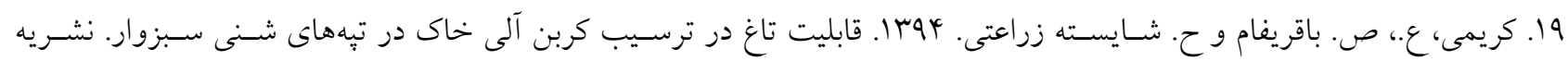

$$
\begin{aligned}
& \text { مديريت خاك و توليد بايدار ه( (1). IAV-Yo。. }
\end{aligned}
$$

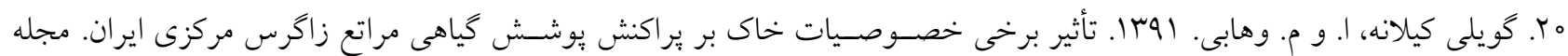

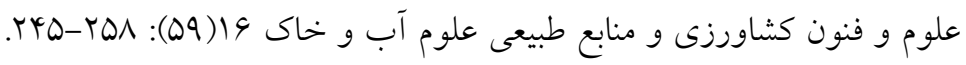

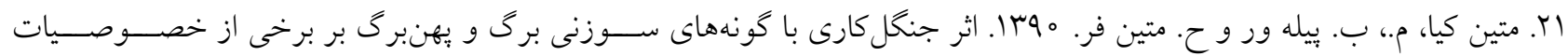

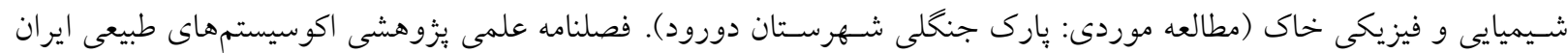

\section{$.19-9 V:(Y) Y$}

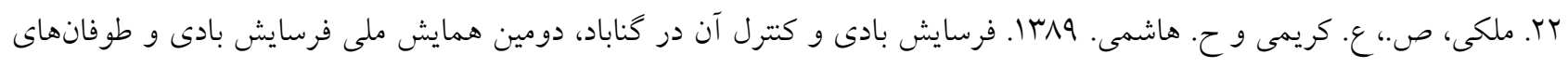

$$
\text { كرد و غبار ه-1. }
$$

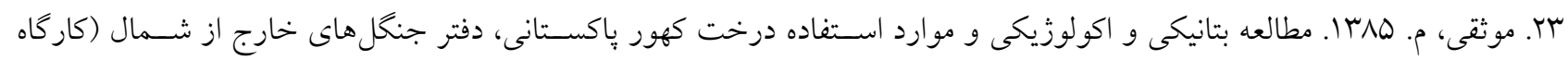

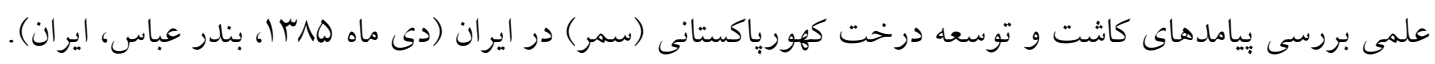

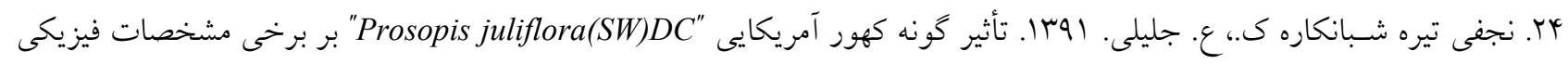

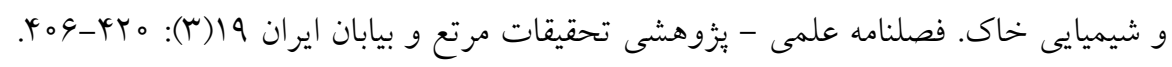

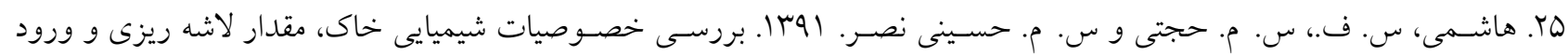

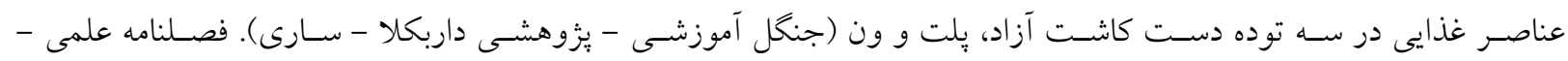

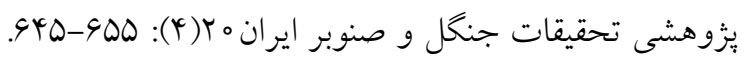

26. Ahmadi, H. 2008.Applied Geomorphology, University of Tehran, Iran, 706 p.

27. Arriaga L. and Y. Maya. 2007. Spatial Variability in Decomposition Rates in a Desert Scrub of North western Mexico. Plant Ecology. 189(2): 213-225.

28. Bhojvaid, P. P., V. R. Timmer and G. Singh. 1991. Reclaiming sodic soils for wheat production by Prosopis juliflora (Swartz) D C afforestation in India. Agrofor. Syst. 34 (2):139-150.

29. Blake, G. R. and K. H. Hartage. 1986. Bulk Density. PP. 363-375. In: Klute, A. (Ed.), Methods of soil analysis. Part 1. (2nd ed.). Agron. Monogr. 9. ASA and SSSA, Madison, WI.

30. Bremner, J. M. and CS. Mulvaney. 1982. Nitrogen total. PP. 595-624. In: Method of soil analysis - part 2: chemical and microbiological methods (2 ndedn) (Miller RH, Kieney DR eds). Agronomy series no. 9, American Society for Agronomy and Soil Sciences, Madison, WI, USA.

31. Charley, Y. L. and E. West. 1975. Plant induced soil chemical pattern in some shrub dominated semi desert ecosystems of Utah. J. Ecol. 63: 945-962.

32. Gee, G. W. and J. W. Bauder. 1986. Particle size analysis. PP. 383-411. In: Klute A. (Eds.), Method of Soil Analysis. part 1.2th Ed. Physical and mineralogical methods Soil Science Society of America Madison Wisconsin USA.

33. Gupta, M. K., S. D. Sharma and A. Mishra. 2003. Soil rehabilitation through afforestation: Evaluation of the 
performance of Prosopis juliflora, Dalbegia sissoo and Eucalyptus tereticornis plantation in a site environment. Arid Land Res. Manage. 17(3): 257-269.

34. Hagos Berhe, D. and A. Nigussie Retta. 2015. Soil Improvement by Trees and Crop Production under Tropical Agroforestry Systems. J. Merit Res. Agri. Sci. Soil Sci. 3(2):18-28

35. He, Z., L. Sh and Y. Harazono. 2007. Wind-Sandy Environment and the effects of Vegetation on Wind Breaking and Dune Fixation in Horqin Sandy Land. China.

36. Famiglietti, J., J. Rudnicki and M. Rodell. 1998. Variability in surface moisture content along a hillslope transect: Rattlesnake Hill, Texas. J. Hydrol. 210: 259- 281.

37. Li, Y., T. Awada, X. Zhou, W. Shang, Y. Chen, X. Zuo, S. Wang, X. Liu and J. Feng. 2012. Mongolian pine plantations enhance soil physico-chemical properties and carbon and nitrogen capacities in semi-arid degraded sandy land in China. Appl. Soil Ecol. 56: 1- 9.

38. Li, Q., Z. Jia, Y. Zhu, Y. Wang, H. Li, D. Yang and X. Zhao. 2015. Spatial Heterogeneity of Soil Nutrients after the Establishment of Caragana intermedia Plantationon Sand Dunes in Alpine Sandy Land of the TibetPlateau. PLoS ONE. 10(5):1-12.

39. Morwin, H. D. and PM. Peach. 1951. Exchangeability of soil potassium in and, silt and clay fractions as influenced by the nature of complementary exchangeable cations. Soil Sci. Soc. Am. J. 15: 125-128.

40. Naseri, S., M. A. Ali Adibi, S. A. Javadi, M. Jafari and M. Zadbar. 2012. Investigation of the Effect of Biological Stabilization Practice on Some Soil Parameters (North East of Iran). J. Rang. Sci. 2(4): 643-653.

41. Olsen, S. R., CV. Cole, FS. Watanabe and LA. Dean. 1954. Estimation of available phosphorus in soils by extraction with sodium bicarbonate. USDA Circula. 939: 1-19.

42. Ovington, J. D. 1953. Studies of the development of woodland conditions under different trees.I. Soils pH. J. Ecol. 4: 13-34.

43. Podrázský, V., O. Holubík, J. Vopravil, T. Khel, W.K. Moser and H. Prknová. 2015. Effects of afforestation on soil structure formation in two climatic regions of the Czech Republic. J. Forest Sci. 61(5): 225-234.

44. Qi, Y. B., Q. R. Chang, M. Y. Liu, J. Liu and T. Chen. 2011. Characteristics of desertified soil in desertification reversing process by artificial vegetation. Agr. Res. Arid Ar. 201, 29(3):180-185

45. Qiong, Z., Z. De-Hui, F. Zhi-Ping and D. K. Lee. 2008. Effect of Land Cover Change on Soil Phosphorus Fractionsin Southeastern Horqin Sandy Land, Northern China. Pedosphere 18(6): 741-748

46. Quansheng, GE., W. Huanjiong, D. Junhu. 2015. Phenological response to climate change in China: a meta-analysis. Glob. Chan. Biol. 21: 265-274.

47. Roades, J. D. 1990. Salinity, electrical conductivity and total dissolved solids. PP. 417-436. In: Sparks D. L. (Eds.), Methods of soil analysis. Part 3. 2th Ed. Chemical methods. Medision Wisconsin USA.

48. Singh, G. 1995. An agroforestry practice for the development of salt lands using Prosopis juliflora and Leptochloa fusca. Agroforestry System 29: 61-75.

49. Thomas, G. W. 1996. Soil pH and soil activity. PP.. 475-490. In: Sparks D. L. (Eds.), Methods of Soil Analysis. part 3. 2th Ed. Chemical methods. Madision Wislonsin USA.

50. Virginia, R. A. and W. M. Jarrel. 1983. Soil properties in a Mesquite dominant Sonoran desert ecosystem. Soil Sci. Soc. Am. J. 47: 138-144.

51. Walkley, A. and I. A. Black. 1934. An examination of the Degtjareff method for determining organic carbon in soils: effect of variations in digestion conditions and of inorganic soil constituents. Soil. Sci. 63 (4): 251-264.

52. Yang, H. J., L. Jiang, L. H. Li, A. Li, M. Y. Wu and S. Q. Wan. 2012. Diversity-dependent stability under mowing and nutrient addition,evidence from a 7-year grassland experiment. Ecol. Lett. 15: 619-626

53. Zhang, Y. and Y. Bi. 2014. Role of the different planting age of seabuckthorn forests to soil amelioration in coal mining subsidence land. Int. J. Coal. Sci. Technol. 1(2):192-197.

54. Zhao, H. L., Y. R. Guo, R. L. Zhou and S. Drake. 2011. The effects of plantation development on biological soil crust and top soil properties in a desert in northern China. Geoderma. 160: 367-372.

55. Zhao, F., D. Kang, X. Han and G. Yang. 2015. Soil stoichiometry and carbon storage in long-term afforestation soil affected by understory vegetation diversity. Ecol. Eng. 74: 415-422. 


\title{
The Effect of Prosopis juliflora Afforestation on Soil Physicochemical Properties in Sand Dunes (Case study: Magran Shush
}

\author{
F. Imani, M. Moradi* and R. Basiri ${ }^{1}$
}

(Received: Feb. 16-2016 ; Accepted : May. 16-2016)

\begin{abstract}
This study was done to evaluate the effect of afforestation in sand dunes at the vicinity of Shush, because of the importance of soil protection and wind erosion in sand dunes, also sand dunes afforestation as an effective and long lasting fixation mechanism. The study site was covered by petroleum mulch about 20 years ago and afforested by Prosopis juliflora. To study the effects of afforestation on sand dunes, two 10 ha afforested sites (25-50 and 75-100 percent canopy coverage) and control were selected. In each of studied site 15 plots were established and soil physiochemical properties were determined. Our result indicated that afforestation caused soil texture to change from sandy to sandy-loam. Also, soil phosphorus, potassium, organic carbon and nitrogen increased in $0-5 \mathrm{~cm}$ soil depth by afforestation that could be because of nutrient absorption from soil depth and returning to the surface by litter fall compared to the control. This study revealed that 25-50 percent canopy coverage resulted in better soil physiochemical properties compared to control site. In conclusion, sand dunes afforestation not only resulted in sand dunes fixation but also soil fertility and long lasting fixation.
\end{abstract}

Key words: crown cover, sand dunes, soil elements, vegetation.

1. Dept. of forestry, Faculty of Natural Resources and Environment, Behbahan Khatam Al-Anbia Univ.of Technology, Behbahan, Iran.

*: Corresponding Author, Email: moradi4@gmail.com 